\title{
Notary and Registrar's Civil Liability for Data Leaking at the Brazilian Electronic Central (E-Notariado)
}

\author{
By Jonatan Vieira Feitosa ${ }^{*} \&$ José Geraldo Romanello Bueno ${ }^{ \pm}$
}

This paper analyses the acts performed by the Brazilian notaries and registrars at electronic databases and the new electronic internet device created by the Brazilian College of Notaries, called E-notariado, which acts as a digital certificate network with the purpose of establishing an Authority Certification. This platform includes various services such as cloud backup, notary clients' biometrics registration, digital signature for notarial acts, and a notary-chain that acts as a notary blockchain and an electronic real estate registry. The study stresses the need for a data protection law, concluding that the civil liability of notaries and registrars related to acts in electronic exchanges is subjective, as long as they respect the requirements established by the Brazilian data protection law. Suggestions to implement data protection are offered, using programs and platforms that benefit the development and the fulfilment of public interests, without harming or weakening the legal security and reliability of notarial acts and public records. Finally, the paper highlights the technological challenges inherent in the fourth industrial revolution, taking place at present.

Keywords: Data leaking; Database; Notarial E-Centrals; Civil Liability of Notaries; Notaries Public; Registry Activity

\section{Introduction}

At present, humanity is experiencing the culmination of the fourth industrial revolution. Society has become digitalised, and thus there is a need for public bodies to be updated, with the aim of monitoring these developments and making actions more swift and effective.

Along with various other fields, the work of notaries and registrars has undergone many changes, and they have gradually ridden themselves of the obsolete means of production of acts, in accordance with the dictates of the fourth revolution and the constantly-changing world. This has resulted in the development of E-Notariado, electronic real estate registration and other internal programs that transform notaries into certifying authorities, allowing notaries and registration officers access to real databases, containing the most sensitive data available today.

\footnotetext{
* Lawyer, Researcher at the LawTech research group, Mackenzie Presbyterian University, Campinas, São Paulo, Brazil. E-mail: Jonatanvieiraf2@gmail.com.

${ }^{ \pm}$Professor of Civil Law, Chairman of Civil Law Dept., Mackenzie Presbyterian University, Campinas, São Paulo, Brazil. E-mail: gromanello@usp.br.
} 
While the new technologies have contributed much to society, they do not lack their own problems and disadvantages. In the context of this paper, these relate to the fundamental juridical assets of the individual and the collective. Unfortunately, complications have been occurring with a growing frequency.

Coinciding with the evolution of technology and both its positive and negative effect on society, the law, by one of its natural characteristics, includes mechanisms for the resolution of possible conflicts and accountability of the causative agents of damages, e.g. Laws $\mathrm{N}^{\circ}$ s 8.935/94 and 13.709/18. Therefore, the objective of this article is to analyse the civil liability of notaries and registrars in cases when they cause damage or injury to the legal assets protected by means of the electronic data bases.

This article begins by addressing the historical evolution of notaries and registrars. Next, we discuss the essential concepts of notarial and registrarial activity, such as public trust, and the differences between notarial and registrarial advertising are explained. Once this is established, we analyse the acts practiced in the electronic databases, the new data storage programs such as the E-Notariado, electronic real estate registry and others. A brief analysis of the categories and types of data resulting from the 2018 data protection law follows, along with a description of the data that these programs use when performing the acts. Finally, we will suggest the scope and limits of responsibility that should be applied to notaries and registrars, and briefly discuss the importance of notaries and registrars in the fourth industrial revolution. In addition, we will propose a manner of implementation that will not harm or weaken the legal security and reliability of notarial acts and public registers.

\section{A Brief Historical Evolution and Legal Nature of Notarial and Registry Activity}

Actions of a notarial and registrarial character were first mentioned in the biblical period, ${ }^{1}$ where various verses cite the actions of scribes during the preparation and writing of acts performed at the time. ${ }^{2}$ Traces of notarial and registrarial activity thus exist from times before the emergence of the State ${ }^{3}$ and of the Law itself, because there was a need to produce documentation to prove different actions and agreements. Soon this task became the domain of specific people who were trusted and confided in.

Contracts from the Sumerian period $(3,500$ to $3,000 \mathrm{BC}),{ }^{4}$ located in southern Mesopotamia, now Iraq and Kuwait, were written on animal skins, proving the existence of a kind of notary at the time. In Egypt, at the apex of the Ancient Empire and the Middle Kingdom, during the years 3,100 and 1,770 B.C, the Egyptians had a template that regulated private agreements. It was from there that the concept of the "subscribing witness" for notarial acts first originated, since

\footnotetext{
${ }^{1}$ Genesis, ch. 2 .

${ }^{2}$ Ferreira \& Rodrigues (2018) at 15.

${ }^{3}$ Erpen (1995) at 37-39.

${ }^{4}$ Pininga (2015).
} 
such witnesses were essential to the work of the scribes who drew up the specific documents. After the document was prepared and signed by three witnesses, it was taken to a priest to affix a seal, giving the document authenticity and ensuring that the document could no longer be altered.

In Greece, the figure of the Mnemosyne appeared, the Greek Goddess of memory. The Mnemon was a memoriser, who formalised all public and private acts. The Roman Empire saw the emergence of the figures most similar to today's notaries and registrars. As the Roman territory expanded, Roman law was concerned with the protection of its conquered people, which marked the emergence of the Tabullarius, Notarius, Argentarius and Tabellios. ${ }^{5}$

Another relevant historical moment of notarial and registrarial activity took place during the years 527-565 AD, a time marked by the imposition of Justinian's Code, when the notary and registrar had servants to assist in the practice of notarial acts.

The term notary ${ }^{6}$ was used for the first time in Portugal in 1283, influenced by the Bologna School, ${ }^{7}$ and the Portuguese dialect was used for the first time in public contracts. As for the structure, these were public-faith preposts, which had not changed much as compared to Justinian's Code.

In Brazil, the functions of the notary and registrar were, by nature, subordinated to the judge, that is, the notary and registrar were linked to a state judge, and did not function independently. No lawyer in private practice could function as notary or registrar unless he was in the public service.

This situation was reinforced with the advent of the 1988 Federal Constitution in conjunction with the 1994 Law on Notaries and Registrars, when tests were formulated in order to authorise notaries and registrars to function independently from the judges.

Following, we would like to survey the importance of the acts performed by notaries and registrars and the public faith granted them by law.

\section{Full Faith and Credit, Publicity in the Acts performed and their Importance}

Notarial and registration law is almost synonymous with speaking in public faith and advertising, but what do the terms 'full faith and credit' and 'advertising' consist of?

According to the Aurélio dictionary, the term faith means belief, trust, or even authentic testimony, written by certain officials, ${ }^{8}$ which has force in the judgment, and the term public means something that is relative or intended for the people, the collective, or the government of a country.

From a technical perspective, Paulo Roberto Benasse, in his legal dictionary, defines full faith and credit as "public trust in the truth or legitimacy of a thing or

\footnotetext{
${ }^{5}$ Ferreira \& Rodrigues (2018) at 16

${ }^{6}$ Jacomino (2019).

${ }^{7}$ Pinho (2018).

${ }^{8}$ Holanda (2000) at 316.
} 
an act emanating from public authority or power in the exercise of its functions", 9 therefore one can define 'public faith' as the trust granted in specific cases by the state to a public or private agent.

Within the context of Brazilian Notarial and Registral Law, 'public faith' means that the people have granted the State a certain trust to represent them, and the State, based on the Brazilian Federal Constitution, grants certain officials the same faith that they perform certain tasks.

Notaries and registrars are officials that have received the public's trust by means of the State, and their acts are considered trustworthy until proven otherwise by judicial means. Notaries are trusted by the public to be instrumental in legal transactions carried out by private individuals, while registrars are trusted by the public to perform legal acts in the strict sense. However, for an official to receive the public's trust, it is necessary that they fulfil certain requirements and formalities. ${ }^{10}$ According to Notary Paulo Roberto Gaiger Ferreira and his alternate, Felipe Leonardo Rodrigues, these formalities include:

A) Being authorised by law;

B) Professional competence;

C) Social value. ${ }^{11}$ The public's trust has been stated in our order through Art. 19, II and Art. 236 of the Federal Constitution of 1988, in addition to the provision of Law No. 8,935/94.

As far as advertising is concerned, notaries and registrars perform a broad public function, ${ }^{12}$ so all acts performed by them should be public and fully accessible to the people, provided that the action was requested and paid for by the individual. ${ }^{13}$ In order to competently discuss advertising, we must separate between notarial advertising and registry advertising. Notarial advertising is exercised by notaries of notes, and refers to that which confers the confidence of the State on business activities executed by individuals, giving cognisance and making them accessible to any interested party. ${ }^{14}$ Registry advertising aims to give effective erga omnes to legal acts, removing them from the inter partes sphere, and causing them to be enforceable against third parties.

Both the concepts, public faith and advertising, concentrate on pursuit of a single objective with significant importance to the law, advancing legal security. ${ }^{15}$

\section{Acts practiced in the Electronic Stations and their Risks}

In the above topics, the primary assumptions of notarial and registral law were analysed, without which the roles of notaries and registrars would not exist.

\footnotetext{
${ }^{9}$ Benasse (2000) at 181.

${ }^{10}$ Chaves \& Rezende (2013) at 113.

${ }^{11}$ Ferreira \& Rodrigues (2018) at 17.

${ }^{12}$ ADI 3.643, voto do rel. min. Ayres Britto, j. 8-11-2006, P, DJ de 16-2-2007.

${ }^{13}$ Brandelli (2016) at 80 .

${ }^{14}$ Brandelli (2016) at 81 .

${ }^{15}$ Enríquez (2012).
} 
Because these are matters of law, they are subject to its general characteristics, described by such classical authors as Professor Tércio Sampaio Ferraz Jr. and the German jurist and philosopher, Karl Engisch ${ }^{16}$.

One of the prime characteristics of the law is dynamism, ${ }^{17}$ which refers to the capacity of the law to adapt according to the evolution of society. With the constant changes arising from the new technologies ${ }^{18}$ that were the results of the fourth industrial revolution, the law has had to adapt in order to regulate such demands, a matter we will soon discuss.

Technological innovations greatly affected the work of notaries and registrars, developing new technological mechanisms for drawing up notarial minutes, the ENotariado system, Notar-chain, ${ }^{19}$ and other programs and applications for data storage, all with the aim of facilitating notarial activities, expanding data storage and making their service more efficient and faster.

The innovative technologies that characterise the fourth industrial revolution allow an integration of the digital world with the real world, offering applications in a myriad of fields in everyday life. With these contemporary technologies, notaries and registrars have had to update their mode of work in order to meet the new demands arising from such a revolution and, as a consequence, notaries and registrars have started to use electronic centrals.

The E-Notariado system was implemented for the use and benefit of notaries. This tool is used as a kind of digital certificate network, aiming to establish the notary public as a certification authority. ${ }^{20}$ Within this platform, one can find several services, such as cloud backup, biometric registration of notary public clients, digital signature for notary public acts, and Notar-chain, ${ }^{21}$ which works as notary public blockchain, making physical documents obsolete and authenticating documents by digital means, with a high degree of security against potential system invasions.

The electronic real estate registry was created in 2009, with the advent of Law No. 11,977, and consists of a database that facilitates the exchange between real estate registry officers and the judiciary and public administration in general, ${ }^{22}$ in addition to storing all the data from the registry office and facilitating the issuing of certificates. Along with the programs mentioned above, notary publics and registration services have programs and internal applications, both to store the signatures and photos of clients and to store more confidential documents, such as wills drawn up by notaries.

The use of these programs by notaries and registrars demonstrates the importance of the implementation of public faith and publicity in the acts practiced within the network. At present, the internet and digital media are not sufficiently

\footnotetext{
${ }^{16}$ Engish (2008) at 393.

${ }^{17}$ Ferraz Junior (2016) at 164.

${ }^{18}$ The fourth industrial revolution began approximately 30 to 40 years after the end of the third industrial revolution, proving the speed with which revolutions have been happening in society, and exhibiting the need for rules and laws to accompany these developments.

${ }^{19}$ Magalhães \& Vendramini (2018).

${ }^{20}$ Autoridade responsável por emitir certificados digitais.

${ }^{21}$ E-Notariado (2019).

${ }^{22}$ SREI (2019).
} 
regulated by the state, and thus there is a need for specific services that add reliability and legal security to the acts practiced by individuals in the digital and electronic world.

The abovementioned programs use users' data, that is, informational elements regarding a person/thing serving as a basis for a judgment. These data are currently considered "the oil of the twenty-first century" ${ }^{23}$ because of the high sums for which companies, such as Google, sell these data to other companies for the purpose of targeted marketing.

Today, we have several kinds of data, some of them stated in Art. 5 of Law no. 13.709:

A) personal data, which refers to an identified or identifiable natural person;

B) sensitive personal data, which refers to racial or ethnic origin, religious conviction, political opinion, union membership or religious, philosophical or political organisation, data concerning health or sex life, genetic or biometric data when linked to a natural person;

C) anonymised data: data relating to a holder who cannot be identified, considering the use of reasonable and available technical means at the time of their processing.

Additional data that must be protected also includes such data as direct personal data where there is no need for other complementary information, indirect personal data that makes a natural person identifiable once presented along with other information, Pseudonymised data where there is no possibility of association with the original natural person, and anonymised data that are not personal data, where the holder cannot be identified. ${ }^{24}$

The Data Protection Law and the doctrine in this regard are self-explanatory. Thus, for the purpose of this article, we will concentrate on the type of data that are used by notaries and registrars in Brazil.

In extrajudicial services offered through its internal electronic centres and through the E-Notariado system, personal data of identified natural persons are used in instances when registration data is stored, such as addresses, photos, signatures, RG (Identity Cards), CPF (Cadastro de Pessoas Físicas), and title of voter, among others. This includes also sensitive data, such as in the case of storage of homoafetive ${ }^{25}$ stable union deeds, or powers of attorney for the sick and declaration deeds that contain any kind of information about race or ethnicity, religious conviction, political opinion, union membership or religious organisation and so on. Sensitive data may also appear in notarial minutes ${ }^{26}$ where the notary records the events in a deed in a tangible manner. An example of sensitive data in notarial minutes is a case involving a notarial act on an intimate video uploaded to the internet. Although most of the data stored by the extrajudicial services are

\footnotetext{
${ }^{23}$ The Economist (2017).

${ }^{24}$ Maldonado, Blum \& Borelli (2019).

${ }^{25}$ Although the homoafetivas stable union deeds are public, it is possible to demand for secrecy through the courts.

${ }^{26}$ In the same sense as the previous footnote.
} 
public, there is the possibility of requesting a restriction by judicial means, a subject we will focus upon next.

Although the technological revolution has changed our life in a positive manner, there are cases in which the same technological devices have caused damage and prejudice due to hacker invasion and data leakage. For example, in 2019 the data of at least 1 million people were exposed on the network due to a failure in the system of ARPEN-SP, which stores all the data of Civil Registry Officers of the State of São Paulo. ${ }^{27}$ Unfortunately, cases like this are increasingly common in our society. For this reason, the law needs to accompany the changes in order to avoid the problems that may be caused by the abovementioned situations and ensure that the legal rights protected by law are not harmed, especially the individual's right to privacy. Following, we will examine the responsibility of notaries and registrars in case of data leakage and the invasion of third parties in their systems.

\section{Civil Liability of Notaries and Registrars for the Leakage of Personal Data in Acts Performed in the Electronic Centres}

In order to develop the argument, it is necessary to differentiate two distinct figures regarding the administration of the electronic centrals and the possible data leaks. First, there is the figure of the operator ${ }^{28}$ of the electronic centrals, that is, the person who actually performs the manipulation of personal data on behalf of the controller ${ }^{29}$. The second figure is that of the notary public or registration officer who controls the central offices, issuing the decisions regarding the processing of personal data.

Regarding civil liability, Silvio Rodrigues ${ }^{30}$ defines it as "the obligation that may be incumbent on one person to repair damage caused by another, by his own fact, or by the fact of persons or things that depend on him". This institute of civil law is one of the most evolved, ${ }^{31}$ as it must follow the evolution of society.

Limited to the notarial and registry realm, civil liability serves to ensure the reliability and safety of services. ${ }^{32}$ The civil liability of notaries and registrars is set forth in Law 8.935/94, and the judiciary power is tasked with overseeing and exercising disciplinary power over the delegates of the public service, according to Article 37 of said law. But which institute applies: objective or subjective civil liability?

It should be noted that notarial and registrarial activity are considered a public service in the broad sense, and the Federal Constitution itself, in Article 236, paragraph 1 , reports that the civil liability of notaries and registrars must be applied by specific law. Therefore, the rules related to consumer law should not be applied,

\footnotetext{
${ }^{27}$ Militão (2019).

${ }^{28}$ Teixeira \& Armelin (2019) at 42.

${ }^{29}$ Lei Federal $\mathrm{n}^{\circ} 13.709$, de 14 de agosto de 2018.

${ }^{30}$ Rodrigues (2002), at Vol. 4, p. 6.

${ }^{31}$ Tartuce (2019) at 337.

${ }^{32}$ Pedroso \& Lamanauskas (2015).
} 
ruling out the institute's incidence of objective civil liability, provided for in Articles 12 and 14 of the Consumer Protection Code. ${ }^{33}$

With the advent of Law 13.286/16 in 2016, Article 22 of Law 8.935/94, which refers to the civil liability of notaries and registrars during the performance of their activities, was amended, exposing notaries and registrars to the institute of subjective civil liability, provided that it is based on malice or guilt, thus safeguarding the right of recourse against their agents.

In fact, there is more than one law applicable to the case in question, causing a contradiction: $^{34}$ Law 8.935/94, referring to notaries and registrars, and Law 13.709/18, which provides for the protection of personal data. For this reason, the Brazilian judiciary system has provided criteria to solve this contradiction.

These chronological and specialty criteria are applied to the case of data leakage by notaries and registrars. The personal data protection law came into force in 2018 and is chronologically newer than Law 8935/94, as amended by Law $13.286 / 16$, hence lex posterior rogat priori. With regard to the specialty criteria, it should be noted that the Data Protection Law, although somewhat generic when it comes to data protection, is more specific than Law 8,935/94, since it deals with an extremely limited matter in the notarial and registry sphere, hence lex specialis derogat generali. There is no mention of hierarchical criteria, since both rules are in the same degree of hierarchy.

It should be noted that the prevailing law on the issue of data leakage is Law No 13.709/18, as it is more specific and newer than Law No 8.935/94, which is applied in cases where the LGPD (The Brazilian General Data Protection Law) does not cover it. Regarding civil liability, which should be applied to notaries and registrars, it should first be established whether notaries and registry officers are public agencies, since the liability applied diverges between public and private agencies.

According to Art. 23, §§ 3 and 4 of Law 13.709/18, notaries and registration officers are to be treated as public authorities in the matter of personal data protection. This legislative statement is based on the fact that extrajudicial services, despite being exercised on a private basis, are delegated activities of the Public Power, as referred to in Article 236 of the Major Law.

Therefore, the notaries public and the registry officers appear as the long arm of the State for the practice of public services sensu lato, as mentioned above.

However, notaries and registrars are, in fact, ambiguous figures, being both public and private. As far as administrative sanctions are concerned, notaries and registrars are not subject to financial sanctions, since they are treated as public bodies for such accountability. According to Article 31 of the Data Protection Act, though, they are obliged to stop violations they encounter during the course of their work, ${ }^{35}$ in accordance with the guidelines of the National Data Protection Authority.

As for civil liability, notaries and registrars should be punished as legal persons under private law. LGPD brings to the system the figure of subjective civil

\footnotetext{
${ }^{33}$ Velter Junior (2018) at 108.

${ }^{34}$ Bobbio (1995) at 91.

${ }^{35}$ Teixeira \& Armelin (2019) at 99.
} 
liability, provided that notaries and registrars have not complied with security, technical or administrative requirements that were put in place in order to protect personal data, unauthorised access, and accidental or illicit situations of destruction, loss, alteration, communication or any form of improper or illicit treatment. Provision No. 74 of the National Council of Justice, put on place on July 31, 2018, provides minimum standards of information technology for the security, integrity and availability of data for the continuity of activity by notary and registry services in Brazil.

Therefore, it must be proven that notaries and registrars acted in malice or failed to repair damages, and that the appropriate measures for data protection were not taken. The exception to this is the right of the notary and registrar to turn against their agents, applying Art. 42, §4 of the LGPD and, alternatively, Law No. $8,935 / 94$.

In cases when the requirements made by law are not met or the operator's lawful instructions are not complied with, the person holding the position of data operator must answer jointly with the controller of the data, which in this case is the notary or registrar. Article 42, I of LGPD is very clear, since in most cases the notary and registrar take all the necessary precautions, but these are not complied with by the operator, causing an "unfair" liability to the notary and registrar.

Article 43 of the Brazilian Data Protection Legislation provides for situations when liability is excluded. This is applicable also to notaries and registrars:

A) when the data processing assigned to it is not carried out;

B) when the processing is carried out, and there has been no violation of the data protection legislation;

C) when the damage results from the exclusive fault of the data subject.

It should be noted that the Data Protection Law does not, at any time, use the characteristic expression of "objective civil liability," i.e. "liable regardless of fault," and it is therefore concluded that the civil liability to be applied to notaries and registrars is subjective, as long as the technical security requirements provided by the law are not met.

\section{Conclusions}

Many critics of the notarial and registrarial functions have stated that these positions would disappear with the evolution of technology, mainly because of the potential for problems emanating from technological developments. However, this statement has been proven wrong, since it is undeniable that notaries and registrars have a primary mission in the fourth industrial revolution, i.e. to serve the public interest through electronic and digital acts, while utilizing appropriate security measures in order to ensure public faith in private electronic acts, without harming or weakening the legal security and reliability of notarial acts and public records.

However, human beings have fundamental rights guaranteed by the Federal Constitution and Federal Laws, some of which are confidentiality, privacy and the 
right to demand erasure of data. Such rights can be violated in case of data leaks, exposing the individual's life to the public through the digital world, causing discomfort and, often, the loss of dignity.

At present, notaries public and registry officials are privy to much personal information, and despite the security that such bodies present, both human and machine errors may, and do, occur.

Notaries and registrars should also be penalised according to the institute of civil responsibility. After conducting an in-depth study of the Brazilian law, it is concluded that the civil responsibility of notaries and registrars should be subjective, including cases when the technical criteria established by the Data Protection Law are not respected.

Data protection must be made effective in the notarial and registry world, and public interest should be guaranteed. This should be achieved without harming or weakening the legal security and reliability of notarial acts and public registries, and requires the creation of specific legislation for data protection by notary and registry officers. Specific hardware and software must be developed, with a high level of security and reliability to guarantee the protection of personal data. Finally, severe penalties should be put in place for hackers and system invaders, who intentionally circumvent all the security measures created for the notary and registrarial systems.

\section{References}

Ahualli, T. \& M. Benacchio (2016). Direito Notarial e Registral: Homenagem às Varas de Registros Públicos da Comarca de São Paulo. 1st ed. São Paulo: Quartier Latin [In Portuguese].

Benasse, P.R. (2000). Dicionário Jurídico de Bolso. Campinas: Bookseller [In Portuguese].

Bertochi, M.B. (2012). 'A responsabilidade civil do notário no Direito Brasileiro em comparação ao direito espanhol' in Revista de Direito Notarial 04:129-152 [In Portuguese].

Maldonado, V.N., Blum, R.O. \& A. Borelli (2019). LGPD: Lei de proteção de dados comentada [livro eletrônico não numerado]. São Paulo: Thomson Reuters Brasil [In Portuguese].

Bobbio, N. (1995). Teoria do Ordenamento Jurídico. 6th ed. Brasília: Universidade de Brasília [In Portuguese].Teoria do Ordenamento Jurídico. 6. ed. Brasília: Universidade de Brasília.

Brandelli, L (2016). Registro de Imóveis. Eficácia material. Rio de Janeiro: Forense [In Portuguese].

Carvalho Filho, J.S. (2007). Manual de Direito Administrativo. Rio de Janeiro: Lumen Juris [In Portuguese].

Chaves, C.F.B \& A.C.F. Rezende. (2013). Tabelionato de Notas. E o Notariado perfeito. $7^{\text {th }}$ ed. São Paulo: Saraiva [In Portuguese].

Engish, K. (2008). Introdução ao Pensamento Jurídico. Lisboa: Fundação Calouste Gulbenkian [In Portuguese].

E-Notariado (2019). E-Notariado Serviço Notarial do século XXI. Brasília: E-Notariado [In Portuguese]. https://www.e-notariado.org.br

Enríquez, N.P. (2012). 'Lomelí. Seguridad Jurídica' in Revista de Direito Notarial 4:197- 
214 [In Spanish].

Erpen, D. A. (1995). 'A atividade Notarial e Registral. Uma organização social préjuridica' in Revista de Direito Imobiliário, 5:35-36 [In Portuguese].

Ferraz Junior, T.S. 2016. Introdução ao estudo do Direito. Técnica, Decisão, Dominação. São Paulo: Atlas [In Portuguese].

Ferreira, P.R.G. \& F.L. Rodrigues. (2018). Tabelionato de Notas I. Teoria geral do Direito Notarial e minutas. 2nd ed. São Paulo: Saraiva [In Portuguese].

The Economist. (2017). 'Fuel of the future.' New Yorker, May 6, 17.

Holanda, A.B. (2000). Miniaurélio. Rio de Janeiro: Nova Fronteira [In Portuguese]

Jacomino, S. (2019). Uma Longa História de Confusões! At: <https://www.irib.org.br/obr as/uma-longa-historia-de-confusoes .

Lei Federal no 13.709 , de 14 de agosto de 2018. Lei Geral de Proteção de Dados Pessoais (LGPD). At <http://www.planalto.gov.br/ccivil_03/_ato2015-2018/2018/lei/L13709. $\mathrm{htm}>$

Magalhães, R. \& A. Vendramini (2018). 'Inovação e sustentabilidade devem estar integradas e processos como os de gestão de risco, desenvolvimento de produtos, gestão de fornecedores e desenvolvimento de pessoas' Os Impactos da Quarta Revolução Industrial: O Brasil será uma potência sustentável com condições de capturar as oportunidades que surgem com as mudanças econômicas, ambientais, sociais e éticas provocadas pelas novas tecnologias?, in Gvexecutivo São Paulo, v. 17, n. 1, p.40-43, jan. 2018. Mensal.

Militão, E. (2019). 'Falha de cartórios expõe dados de ao menos 1 milhão de pais, mães e filhos' Bol Notícias [In Portuguese]. https://www.bol.uol.com.br/noticias/2019/10/ 29/falha-de-cartorios-expoe-dadosde-ao-menos-1-milhao-de-pais-maes-e-filhos.htm

Pedroso, R. \& M.F. Lamanauskas (2015). Direito notarial e registral atual. 2. ed. Rio de Janeiro: Forense. livro eletrônico não numerado [In Portuguese].

Pereira, F.Z. (2019). 'Dos princípios de regência dos serviços notariais e de registro: Garantia da publicidade, autenticidade, segurança e eficácia' in Revista de Direito Notarial 10: 141-161 [In Portuguese].

Pininga, T.J.C. (2015). 'Entre Paságarda e Suméria. Fronteiras da lírica em Manuel Bandeira e Fernando Monteiro' Ph.D. diss., Universidade Federal de Pernambuco [In Portuguese].

Pinho, R.V.P.R. (2018). A independência jurídica do notário e do registrador. 2018.187 f. Dissertação (Mestrado em Direito) - Programa de Estudos Pós-Graduados em Direito, Pontifícia Universidade Católica de São Paulo, São Paulo [In Portuguese].

Rodrigues, S. (2002). Direito Civil: Responsabilidade Civil. São Paulo: Saraiva [In Portuguese].

SREI (2019). Sistema de Registro Eletrônico de Imóveis (SREI). at: <https://www.cnj.jus.

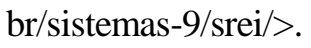

Soares, M.G. (2018). 'A quarta revolução industrial e seus possíveis efeitos no direito, economia e política.' Universidade Autônoma de Lisboa [In Portuguese]. https://www.migalhas.com.br/arquivos/2018/4/art20180427-05.pdf

Tartuce, F. (2019). Direito Civil: Direito das obrigações e responsabilidade civil. Rio de Janeiro: Forense [In Portuguese].

Teixeira, T. \& R.M. Armelin (2019). Lei Geral de Proteção de Dados Pessoais: Comentada artigo por artigo. Salvador: Jus Podivm [In Portuguese].

Velter Junior, M.M. (2018). 'Responsabilidade civil por atos praticados por notários e registradores' Ph.D. diss., Universidade Federal de Santa Catarina [In Portuguese]. 
